\title{
Chemical and sulfur isotopic composition of precipitation in Beijing, China
}

\author{
Guangxu Zhu ${ }^{1,2} \cdot$ Qingjun Guo $^{1} \cdot$ Tongbin Chen $^{1} \cdot$ Yunchao Lang $^{2} \cdot$ Marc Peters $^{1}$ • \\ Liyan Tian ${ }^{1} \cdot$ Hanzhi Zhang ${ }^{1} \cdot$ Chunyu Wang ${ }^{1}$
}

Received: 4 June 2015 / Accepted: 3 November 2015 /Published online: 16 November 2015

(C) Springer-Verlag Berlin Heidelberg 2015

\begin{abstract}
China is experiencing serious acid rain contamination, with Beijing among the worst-hit areas. To understand the chemical feature and the origin of inorganic ions in precipitation of Beijing, 128 precipitation samples were collected and analyzed for major water-soluble ions and $\delta^{34} \mathrm{~S}$. The $\mathrm{pH}$ values ranged from 3.68 to 7.81 and showed a volume weighted average value (VWA) of 5.02, with a frequency of acid rain of $26.8 \%$. The VWA value of electrical conductivity (EC) was $68.6 \mu \mathrm{S} / \mathrm{cm}$, which was nearly 4 times higher than the background value of northern China. $\mathrm{Ca}^{2+}$ represented the main cation; $\mathrm{SO}_{4}{ }^{2-}$ and $\mathrm{NO}_{3}{ }^{-}$were the dominant anion in precipitation. Our study showed that $\mathrm{SO}_{4}{ }^{2-}$ and $\mathrm{NO}_{3}{ }^{-}$originated from coal and fossil fuel combustion; $\mathrm{Ca}^{2+}, \mathrm{Mg}^{2+}$, and $\mathrm{K}^{+}$ were from the continental sources. The $\delta^{34} \mathrm{~S}$ value of $\mathrm{SO}_{4}{ }^{2-}$ in precipitation ranged from +2.1 to $+12.8 \%$ with an average value of $+4.7 \%$. The $\delta^{34} \mathrm{~S}$ value showed a winter maximum and a summer minimum tendency, which was mainly associated with temperature-dependent isotope equilibrium fractionation as well as combustion of coal with relatively positive $\delta^{34} \mathrm{~S}$ values in winter. Moreover, the $\delta^{34} \mathrm{~S}$ values revealed that atmospheric sulfur in Beijing are mainly correlated to coal
\end{abstract}

Responsible editor: Gerhard Lammel

Guangxu Zhu

zhuguangxu@mail.gyig.ac.cn

Qingjun Guo

guoqj@igsnrr.ac.cn

1 Center for Environmental Remediation, Institute of Geographic Sciences and Natural Resources Research, Chinese Academy of Sciences, Beijing 100101, China

2 State Key Laboratory of Environmental Geochemistry, Institute of Geochemistry, Chinese Academy of Sciences, Guiyang 550002, China burning and traffic emission; coal combustion constituted a significant fraction of the $\mathrm{SO}_{4}{ }^{2-}$ in winter precipitation.

Keywords Chemical composition · Sources · Sulfur isotope · Precipitation $\cdot$ Beijing

\section{Introduction}

Acid rain is known to result in serious environmental damage in sensitive environments (Bytnerowicz et al. 2005). Hence, in recent years, more attention was paid to acid rain, which became a major issue in the field of environmental science of the 21st century (Likens et al. 1996; Evans et al. 2005). China is one of the three regions in the world with the highest occurrence of acid rain, next to Europe and North America (Zhang et al. 2010b). Widespread acid rain was observed in southern and southwestern China before the 1990s (Zhao et al. 1988; Wang and Wang 1995), and more recently, it has extended to eastern and central China (Huang et al. 2008; Xie et al. 2009; Tang et al. 2010). Beijing is located out of the traditional regions impacted by acid rain in China. However, Beijing has experienced rapid urbanization and motorization in the past three decades. Previous studies pointed out that Beijing has suffered from acid rain pollution in the recent past (Tang et al. 2005; Xu et al. 2012).

The chemical compositions of rainwater play an important role in scavenging soluble components from the atmosphere and helps to understand the actual status and level of acid rain (Hu et al. 2003). Moreover, investigations on the precipitation chemistry could provide a deeper insight into the changes and other characteristics of local or regional atmospheric pollution (Calvo et al. 2010). The origin of acid rain can be determined through the studies of chemical composition in rainwater, also combined with the meteorological information (Seto and Hara 
2006). Monitoring the amount, distribution and the chemical composition of precipitation are essential in environmental studies.

The atmosphere contains a variety of sulfur species derived from a number of potential sulfur sources. The latter can be separated into natural and anthropogenic sources. Natural sources include volcanic eruptions, the release of $\mathrm{H}_{2} \mathrm{~S}$ by biological reduction in ocean anoxic environments and wetlands, marine salt, terrigenous biogenic volatile sulfide, and seaweed dimethylsulfide. Anthropogenic sources are represented by fossil fuel and coal combustion, smelting of metal sulfides, as well as sulfuric acid production (Canfield 2001; Mandeville et al. 2009). Sulfur from different sources shows distinct sulfur isotopic compositions depending on the isotope value of each source material (Lang et al. 2011). Therefore, the sulfur isotope ratio of $\mathrm{SO}_{2}$ and sulfate in the atmosphere must be influenced by various isotopic source values. Sulfur isotopes have been widely used in the field of environmental geochemistry to trace the sources and fate of sulfur (e.g., Xiao and Liu 2002; Pruett et al. 2004; Ding et al. 2013; Yang et al. 2015). The sulfur isotopic signatures of rainwater sulfate may be used to delineate anthropogenic sulfur in the atmosphere, provided the isotopic composition of pollutant sulfur is distinct from that of sulfur from natural sources. Identification of atmospheric sulfur sources in rainwater has been conducted mainly in the acid rain regions through sulfur isotope analysis (Herut et al. 1995; Mast et al. 2001; Xiao et al. 2011a, b, 2014; Bai and Wang 2014). However, systematic observations on the chemical composition of precipitation combined with analysis of the $\delta^{34} \mathrm{~S}$ values have not been carried out in Beijing.

For the present study, we analyzed the chemical and sulfur isotopic composition of 128 precipitation samples collected continuously from September 2010 to October 2013 in the Beijing urban area. The objectives of this study are to (1) describe the pollution level and the chemical characteristics of precipitation in Beijing; (2) present and discuss the chemical composition and sulfur isotopic characteristics of rainwater; and (3) identify the sources of the chemical compounds in rainwater by analyzing the precipitation chemistry and $\delta^{34} \mathrm{~S}$ values of dissolved sulfide. The data can be used for future strategies to reduce atmospheric pollution and to prevent further generation of acid rain in Beijing.

\section{Sampling and analytical methods}

\section{Study area}

Beijing is located in the north of China at $39.4^{\circ} \mathrm{N}-41.6^{\circ} \mathrm{N}$ and $115.7^{\circ} \mathrm{E}-117.4^{\circ} \mathrm{E}$ and comprises around $16411 \mathrm{~km}^{2}$. The city lies near the western slopes of the Yanshan Mountains, about
$150 \mathrm{~km}$ to the west of the Bohai Sea at an altitude between 20 and $60 \mathrm{~m}$ above sea level. Beijing is in a zone with a semihumid continental monsoon climate with hot and humid summers and cold and dry winters. The mean annual temperature is $12.8^{\circ} \mathrm{C}$. The average annual precipitation is $548 \mathrm{~mm}$. About $80 \%$ of the precipitation occurs between June and September (Statistical Yearbook of Beijing 2013).

\section{Sampling and chemical analysis}

The sampling site was located on a building roof of the Institute of Geographic Sciences and Natural Resources Research, Chinese Academy of Sciences (Fig. 1), which is adjacent to the Beijing Olympic Forest Park, between the 4th and 5th ring road in the northwest of Beijing $\left(40^{\circ} 0^{\prime} 7.3^{\prime \prime}\right.$ $\left.\mathrm{N}, 116^{\circ} 22^{\prime} 45.1^{\prime \prime} \mathrm{E}\right)$. Rain from precipitation events were sampled with $50 \mathrm{~L}$ polyethylene buckets $(30 \mathrm{~cm}$ diameter and $50 \mathrm{~cm}$ height) that were fixed at approximately $1.5 \mathrm{~m}$ above the roof. In most cases, samples were collected from the beginning to the end of the precipitation events. Before sampling, the buckets were cleaned with $2 \mathrm{~N}$ hydrochloric acid solution and rinsed with Milli-Q water. To minimize the influence of dry deposition, the buckets were deployed for sampling immediately prior to precipitation events and recovered soon after each event. The amount of precipitation and the duration of the event were recorded. In total 128 , samples were collected in the time from September 2010 to October 2013 (no precipitation after October 22th 2013). These samples represent about $85 \%$ of the total precipitation events that occurred in the Beijing area during the study period. Nineteen samples did not provide enough material for sulfur isotope analyses.

Immediately after arrival at the laboratory, $\mathrm{pH}$ and electrical conductivity (EC) of the water samples were measured using a multi parameter $\mathrm{pH}$ meter (SX731, Sanxin). The water samples were subsequently filtrated through $0.45 \mu \mathrm{m}$ pore size membrane acetate filters. A subsample of each water sample $(15 \mathrm{~mL})$ was cooled at $4{ }^{\circ} \mathrm{C}$ for the determination of major anions and cations. Major anions $\left(\mathrm{Cl}^{-}, \mathrm{SO}_{4}{ }^{2-}, \mathrm{NO}_{3}{ }^{-}\right.$, $\mathrm{F}^{-}$) were quantitatively determined by ion chromatography (ICS-900, Dionex). The detection limits of $\mathrm{Cl}^{-}, \mathrm{NO}_{3}^{-}, \mathrm{F}^{-}$, and $\mathrm{SO}_{4}{ }^{2-}$ ions were found to be $0.01,0.01,0.01$, and $0.02 \mathrm{mg} / \mathrm{L}$, respectively. Reproducibility of results was better than $5 \%$ for all major anions. Inductively coupled plasma optical emission spectrometry (ICP-OES, Optima 5300DV, PerkinElmer) was used to measure major cations $\left(\mathrm{K}^{+}, \mathrm{Na}^{+}\right.$, $\mathrm{Ca}^{2+}, \mathrm{Mg}^{2+}$. The detection limits of $\mathrm{K}^{+}, \mathrm{Na}^{+}, \mathrm{Ca}^{2+}$, and $\mathrm{Mg}^{2+}$ ions were found to be $0.004,0.002,0.010$, and $0.003 \mathrm{mg} / \mathrm{L}$, respectively. Reproducibility of results was better than $5 \%$ for all major cations. Reagent and procedural blanks were determined in parallel to the sample treatment using identical procedures, and the blanks were all below the detection limit of the measure species. The analytical precision of the data are 
Fig. 1 Map showing the sampling sites in Beijing. $P S$ precipitation sample site

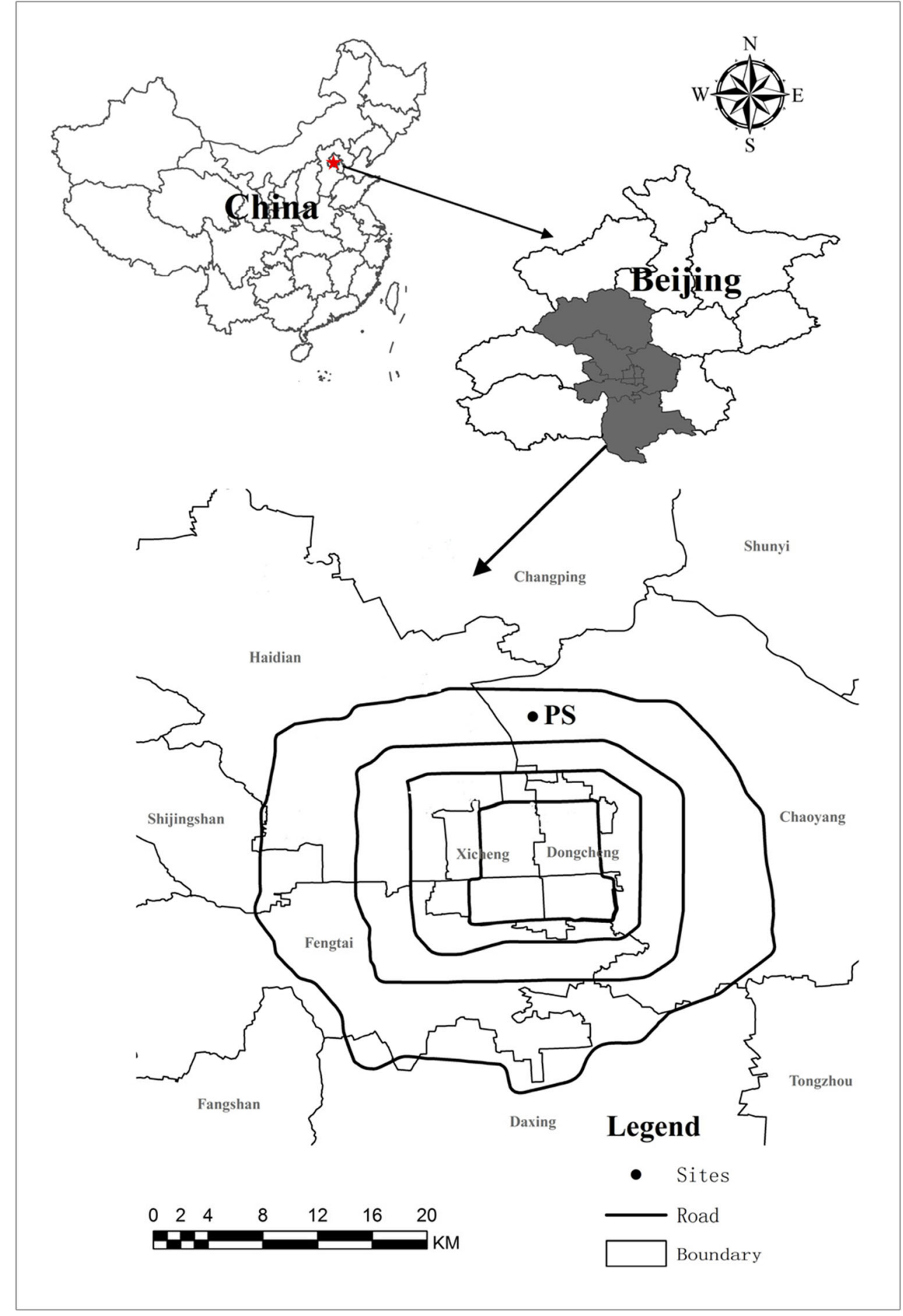

better than $\pm 5 \%$. Analyses of major ions were conducted within 2 weeks after sampling.

The remaining subsamples were acidified by ultra-pure hydrochloric acid $(\mathrm{pH}<2)$ and treated with $10 \%$ barium chloride $\left(\mathrm{BaCl}_{2}\right)$ solution in order to precipitate the dissolved sulfate as $\mathrm{BaSO}_{4}$. After precipitation, the samples were heated up to 70 $80{ }^{\circ} \mathrm{C}$ for $2 \mathrm{~h}$ and filtered through $0.45 \mu \mathrm{m}$ membrane acetate filters. The precipitates $\left(\mathrm{BaSO}_{4}\right)$ on the filters were rinsed with Milli-Q water and oven-dried at 40 to $50{ }^{\circ} \mathrm{C}$.

Approximately $250 \mu \mathrm{g}$ of $\mathrm{BaSO}_{4}$ precipitate was used for the determination of $\delta^{34} \mathrm{~S}$, using elemental analyzercontinuous flow-isotope ratio mass spectrometry (EA-CFIRMS) at the Institute of Geology and Paleontology, University of Münster, Germany. The analytical results are 
expressed in the usual $\delta$ notation in per mil, relative to the Canyon Diablo Troilite (CDT) standard. The standard deviation of the isotopic measurements was $\pm 0.3 \%$.

Statistical analyses were performed with SPSS 22.0 (Statistical Package for the Social Science) and EXCEL software.

\section{Results and discussion}

\section{pH and EC distribution}

Seventy of the 128 precipitation samples were collected in summer (June to August), which exhibits $54.7 \%$ of the annual precipitation, whereas autumn, spring, and winter occupied 28,16 , and 14 rainwater samples, respectively. The $\mathrm{pH}$ value of the 128 precipitation samples varied from 3.68 to 7.81 with an arithmetic average of 6.21 and a volume weighted average (VWA) value of 5.02. $26.8 \%$ of the total rainwater samples can be classified as acid rain $(\mathrm{pH}<5.6)$. Specifically, the annual fraction of acid rain was $29 \%, 11 \%$, and $38 \%$ in the year 2011, 2012 and 2013, respectively, indicating an apparent yearly variation of acid rain pollution. Approximately $80 \%$ of the acid rain was only slightly acidic $(4.5 \leq \mathrm{pH}<5.6)$. Moreover, more than $44 \%$ of the sampled precipitation showed intermediate $\mathrm{pH}$ values between 6.0 and 7.0 (Fig. 2).

A seasonal variation in the volume weighted average $\mathrm{pH}$ values and in the acid rain fraction could be observed. The $\mathrm{pH}$ values during autumn and summer were lower than in spring and winter (Fig. 3); hence, the fraction of acidic precipitation was also higher in autumn and summer compared to winter and spring. This is comparable to the results from other regions in North China (Shen et al. 2012; Zhang et al. 2012) but reverse to data from Hangzhou (Xu et al. 2011) and Anhui (Huang et al. 2012) in the south of China. The acidity of the precipitation depends on the concentrations of acid-forming ions and of alkaline species neutralizing the acidity (Zhang et al. 2007). In northern China, storm events occur with high frequency from December to April, which transport crustal

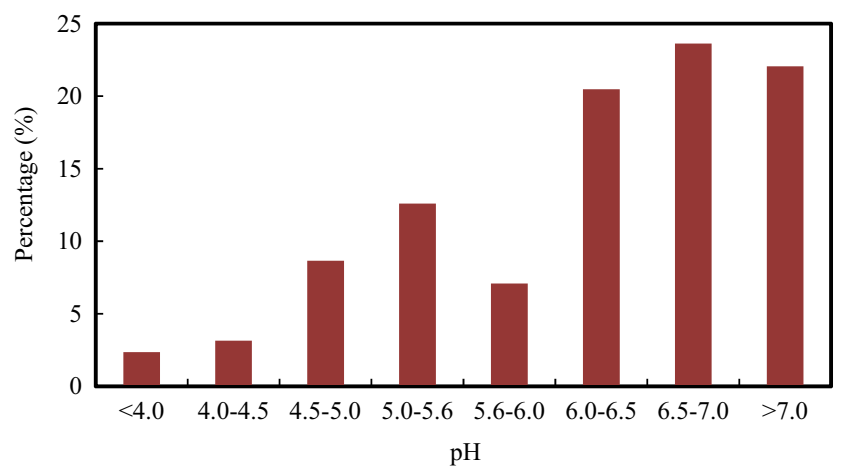

Fig. 2 Frequency distribution of $\mathrm{pH}$ in precipitations from Beijing

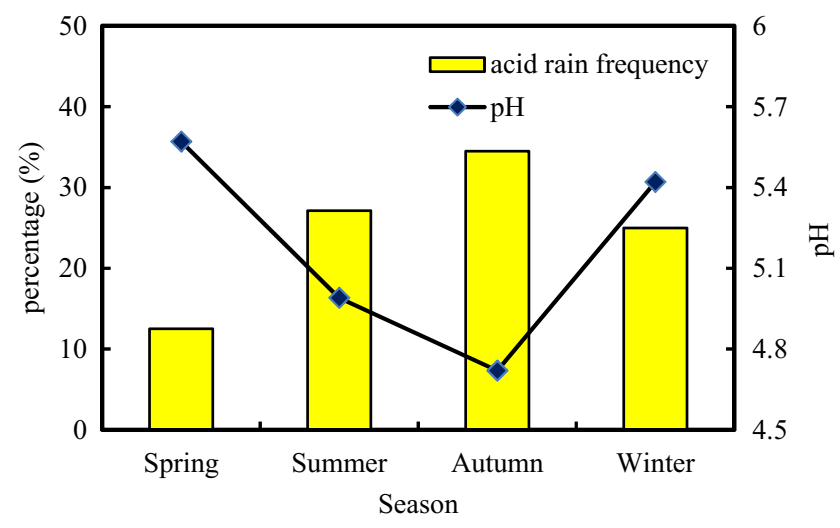

Fig. 3 Seasonal variations of average $\mathrm{pH}$ values and acidification frequency of precipitations

dust particles into the atmosphere. These particles persist in the air for a long time and can accumulate to a relatively large amount (Han et al. 2005). During the rainfall events, the large amount of alkaline particles could neutralize the acid-forming ions. In the rainy season, alkaline species were scavenged by frequent precipitation, resulting in poor neutralization and more acid rain in summer and autumn.

Electric conductivity of precipitation is a good indicator for the amount of total soluble ionic components in the atmosphere and the anthropogenic impact (Arsene et al. 2007). The electric conductivity (EC) of the precipitation samples varied from 10.1 to $370.2 \mu \mathrm{S} / \mathrm{cm}$ with a VWA value of $68.6 \mu \mathrm{S} / \mathrm{cm}$, which is significantly higher than the average $\mathrm{EC}$ value of $14.8 \mu \mathrm{S} / \mathrm{cm}$ for rainwater samples from the Waliguan Mountain located at the eastern tip of QinghaiTibetan plateau, World Meteorological Organization (WMO). This location represents the background monitoring site for the chemical composition of precipitation in northern China (Tang et al. 2000). The relatively high EC values of the sampled precipitation reflect a rather high degree of atmospheric pollution in Beijing.

An inverse relationship between the amount of precipitation and EC values could be observed (Fig. 4); higher EC values correlate with little amounts of precipitation $(<10 \mathrm{~mm})$. During the initial stages of the rainfall event,

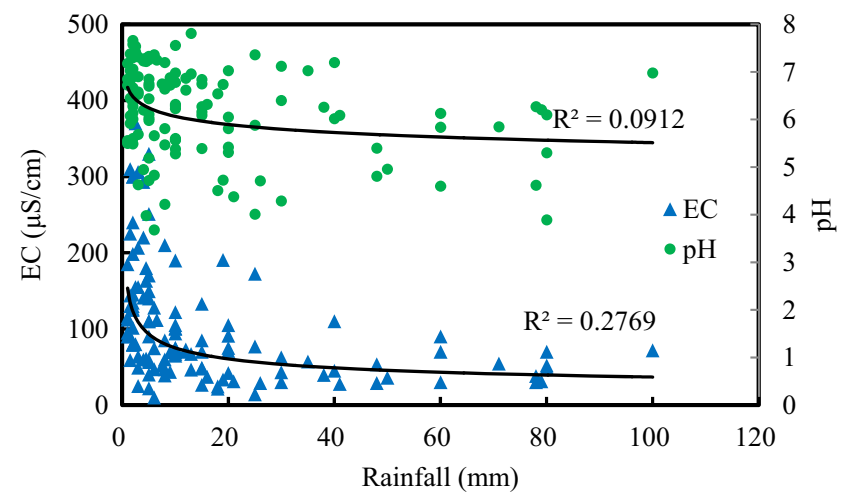

Fig. 4 The relationship of $\mathrm{pH}$ and electrical conductivity with rainfall 
rainwater absorbed the atmospheric pollutants rapidly, resulting in high EC. After that the ion concentrations of the precipitation decreased due to dilution and the EC consequently, showed an obvious descending trend. However, no correlation between $\mathrm{pH}$ and the amount of rain could be seen.

\section{Ion concentrations in precipitation}

The concentrations of major ions in the precipitation samples are given in Table 1. The average concentration of ionic species in precipitation decreased in the following order: $\mathrm{SO}_{4}{ }^{2-}>$ $\mathrm{Ca}^{2+}>\mathrm{NO}_{3}{ }^{-}>\mathrm{Cl}^{-}>\mathrm{F}^{-}>\mathrm{Mg}^{2+}>\mathrm{Na}^{+}>\mathrm{K}^{+}>\mathrm{H}^{+}$(VWA). The average concentrations of $\mathrm{SO}_{4}{ }^{2-}, \mathrm{NO}_{3}{ }^{-}, \mathrm{Cl}^{-}$, and $\mathrm{F}^{-}$were $279,147.6,121.9$, and $63.1 \mu \mathrm{eq} / \mathrm{L}$ with maximum of $4299.4,1951.3,1018.3$, and $271.5 \mu \mathrm{eq} / \mathrm{L}$, respectively. $\mathrm{SO}_{4}{ }^{2}$ represents the predominant anion accounting for $45.6 \%$ of the total anion load, due to the fact that coal represents the major energy source in China and the contribution of coal burning to atmospheric sulfur oxide is significant (Aas et al. 2007; Li and Leung 2012). The second most abundant anion was $\mathrm{NO}_{3}{ }^{-}$, and sum of $\mathrm{SO}_{4}{ }^{2-}$ and $\mathrm{NO}_{3}{ }^{-}$account for $44.2-$ $98.3 \%$ of the total anions. The average $\mathrm{SO}_{4}{ }^{2-} / \mathrm{NO}_{3}{ }^{-}$ratio was 1.89, suggesting that acid rain pollution in Beijing is still sulfur type with a trend to sulfuric-nitrous mixed type, which can be ascribed to reduced $\mathrm{SO}_{2}$ emissions and the expansion of industrial activities as well as the rapid increase of the number of motor vehicles in the past years. The average $\mathrm{SO}_{4}{ }^{2-} / \mathrm{NO}_{3}{ }^{-}$ ratio between the seasons followed the order: winter (5.22) $>$ spring (2.53) > autumn (1.84) > summer (1.72). These can be ascribed to a significantly increased degree of coal combustion in the cold season compared to the warm season.

$\mathrm{Ca}^{2+}$ is the most abundant cation with a VWA concentration of $182.3 \mu \mathrm{eq} / \mathrm{L}$ and a maximum value of $3997.5 \mu \mathrm{eq} / \mathrm{L}$, followed in decreasing order by $\mathrm{Mg}^{2+}, \mathrm{Na}^{+}, \mathrm{K}^{+}$, and $\mathrm{H}^{+}$. Most of the VWA values are lower than the arithmetic average (AA) values indicating that higher concentrations of ions are usually associated with low precipitation. It was mainly due to the removal of particles through washout in the initial phases of precipitation (Hontoria et al. 2003). The concentration data showed relatively high standard deviations, indicating a large variability in the cation and anion concentrations in the precipitation events.

\section{Source identification of major ions in precipitation}

In order to identify the association among ions and get a quick overview of the possible source identification of major ions in precipitation, correlation coefficients $(R)$ between ions in the rainwater were calculated. Data for concentrations of ions were not normally distributed and therefore analyzed after logarithmic transformation. As shown from the inspection of these values (Table 2), significant correlations existed between $\mathrm{Ca}^{2+}$ and $\mathrm{Mg}^{2+}(R=0.933), \mathrm{Ca}^{2+}$ and $\mathrm{K}^{+}(R=0.825)$, as well as $\mathrm{Mg}^{2+}$ and $\mathrm{K}^{+}(R=0.801)$, suggesting their origin from similar sources, because of their common occurrence of these ions from a crustal origin. The good correlation between $\mathrm{SO}_{4}{ }^{2-}$ and $\mathrm{NO}_{3}{ }^{-}(R=0.640)$ might be attributable to their similar chemical behavior in precipitation and the co-emission of their precursor compounds $\left(\mathrm{SO}_{2}\right.$ and $\mathrm{NO}_{x}$ ) from the combustion of fossil fuel and industrial activities. $\mathrm{H}^{+}$showed no correlation with any other anions and had significant negative correlation with base cations. These correlations indicate that acidic anions are neutralized by base cations. The correlation of $\mathrm{SO}_{4}{ }^{2-}$ with $\mathrm{Ca}^{2+}, \mathrm{K}^{+}$, and $\mathrm{Mg}^{2+}(R=0.829,0.816$, and 0.832 , respectively), as well as of $\mathrm{NO}_{3}{ }^{-}$with $\mathrm{Ca}^{2+}$ and $\mathrm{K}^{+}$and $\mathrm{Mg}^{2+}$ ( $R=0.592,0.591$, and 0.598 , respectively) supported this suggestion. Moreover, this indicates that acid pollutants might be absorbed on the surface of particulate matter and react with cations. Positive correlations are obtained between $\mathrm{Cl}^{-}$and other ions; $\mathrm{F}^{-}$correlated only poorly with other ions, except with $\mathrm{NO}_{3}^{-}$.

Except for anthropogenic emissions, the chemical composition of rainwater is mainly affected by sea salts, crustal dust from wind erosion, provided that contributions from volcanic and other natural sources are negligible (Négrel et al. 2007). To further derive these fractions, $\mathrm{Na}$ and $\mathrm{Ca}$ were taken as reference element for seawater and continental crust, respectively (Cao et al. 2009). The sea salt fraction (SSF), crust
Table 1 Concentrations $(\mu \mathrm{eq} / \mathrm{L})$ of major ions in precipitation from Beijing

\begin{tabular}{lllllll}
\hline Ions & Samples & Maximum & Minimum & VWA & AA & Standard deviation \\
\hline $\mathrm{SO}_{4}^{2-}$ & 128 & 4299.4 & 46.4 & 279 & 546.3 & 619.2 \\
$\mathrm{NO}_{3}{ }^{-}$ & 128 & 1951.3 & 21.4 & 147.6 & 218.4 & 262.9 \\
$\mathrm{Cl}^{-}$ & 119 & 1018.3 & 8.9 & 121.9 & 155.2 & 206.5 \\
$\mathrm{~F}^{-}$ & 115 & 271.5 & 26.5 & 63.1 & 95.8 & 55.6 \\
$\mathrm{Ca}^{2+}$ & 128 & 3997.5 & 14.1 & 182.2 & 489.5 & 655.3 \\
$\mathrm{Mg}^{2+}$ & 128 & 539 & 4.3 & 34.3 & 75.0 & 87 \\
$\mathrm{~K}^{+}$ & 128 & 239.6 & 0.66 & 13.2 & 28.8 & 36.1 \\
$\mathrm{Na}^{+}$ & 128 & 935.6 & 0.97 & 26.3 & 74.9 & 151.1 \\
$\mathrm{H}^{+}$ & 128 & 208.9 & 0.02 & 10.8 & 8.0 & 26.4 \\
\hline
\end{tabular}

$V W A$ volume weighted average; $A A$ arithmetic average 
Table 2 Matrix of correlation coefficients among major ions and conductivity in precipitation

\begin{tabular}{|c|c|c|c|c|c|c|c|c|c|}
\hline Ions & $\mathrm{SO}_{4}^{2-}$ & $\mathrm{NO}_{3}^{-}$ & $\mathrm{H}^{+}$ & $\mathrm{Ca}^{2+}$ & $\mathrm{K}^{+}$ & $\mathrm{Mg}^{2+}$ & $\mathrm{Na}^{+}$ & $\mathrm{Cl}^{-}$ & $\mathrm{F}^{-}$ \\
\hline $\mathrm{SO}_{4}{ }^{2-}$ & 1 & & & & & & & & \\
\hline $\mathrm{NO}_{3}^{-}$ & $0.640^{\mathrm{a}}$ & 1 & & & & & & & \\
\hline $\mathrm{H}^{+}$ & $-0.218^{\mathrm{b}}$ & $-0.209^{b}$ & 1 & & & & & & \\
\hline $\mathrm{Ca}^{2+}$ & $0.829^{\mathrm{a}}$ & $0.592^{\mathrm{a}}$ & $-0.324^{\mathrm{a}}$ & 1 & & & & & \\
\hline $\mathrm{K}^{+}$ & $0.816^{\mathrm{a}}$ & $0.591^{\mathrm{a}}$ & $-0.350^{\mathrm{a}}$ & $0.825^{\mathrm{a}}$ & 1 & & & & \\
\hline $\mathrm{Mg}^{2+}$ & $0.832^{\mathrm{a}}$ & $0.598^{\mathrm{a}}$ & $-0.379^{\mathrm{a}}$ & $0.933^{\mathrm{a}}$ & $0.801^{\mathrm{a}}$ & 1 & & & \\
\hline $\mathrm{Na}^{+}$ & $0.809^{\mathrm{a}}$ & $0.473^{\mathrm{a}}$ & $-0.219^{\mathrm{a}}$ & $0.778^{\mathrm{a}}$ & $0.817^{\mathrm{a}}$ & $0.766^{\mathrm{a}}$ & 1 & & \\
\hline $\mathrm{Cl}^{-}$ & $0.431^{\mathrm{a}}$ & $0.290^{\mathrm{a}}$ & 0.070 & $0.294^{\mathrm{a}}$ & $0.348^{\mathrm{a}}$ & $0.322^{\mathrm{a}}$ & $0.349^{\mathrm{a}}$ & 1 & \\
\hline $\mathrm{F}^{-}$ & 0.108 & $0.535^{\mathrm{a}}$ & -0.248 & 0.138 & 0.094 & 0.082 & 0.194 & $0.211^{\mathrm{b}}$ & 1 \\
\hline
\end{tabular}

${ }^{\text {a }}$ Correlation is significant at the 0.01 level (2-tailed)

${ }^{\mathrm{b}}$ Correlation is significant at the 0.05 level (2-tailed) fraction $(\mathrm{CF})$, and anthropogenic fraction $(\mathrm{AF})$ were calculated using the following equations:

$$
\begin{aligned}
& \% \mathrm{SSF}=100\left(X / \mathrm{Na}^{+}\right)_{\text {seawater }} /\left(X / \mathrm{Na}^{+}\right)_{\text {rainwater }} \\
& \% \mathrm{CF}=100\left(X / \mathrm{Ca}^{2+}\right)_{\text {crust }} /\left(X / \mathrm{Ca}^{2+}\right)_{\text {rainwater }} \\
& \% \mathrm{AF}=100-\mathrm{SSF}-\mathrm{CF}
\end{aligned}
$$

where $X$ is the ion of interest. The elemental ratios $\left(X / \mathrm{Na}^{+}\right)$ were determined according to the composition of seawater given by Berner and Berner (1987), $X / \mathrm{Ca}^{2+}$ of the crust is the ratio from crustal composition (Taylor 1964). Since it is difficult to distinguish which parts of $\mathrm{K}^{+}, \mathrm{Mg}^{2+}$, and $\mathrm{Ca}^{2+}$ stem from crustal or anthropogenic sources (Wu and Han 2015), we merged these two sources into a non-seasalt source.

The contributions from different sources to the chemical composition of rainwater are shown in Table 3. It is revealed that nearly half of $\mathrm{Cl}^{-}$and small amounts of $\mathrm{Mg}^{2+}(20.7 \%)$ were of marine origin. In addition, the proportion of $\mathrm{Cl}^{-} \mathrm{com}-$ ing from anthropogenic sources is about $48.4 \%$. The

\begin{tabular}{|c|c|c|c|}
\hline \multirow[t]{2}{*}{ Ions } & \multirow{2}{*}{$\begin{array}{l}\text { Sea salt } \\
\text { fraction (\%) }\end{array}$} & \multicolumn{2}{|l|}{ Terrestrial fraction } \\
\hline & & Crust fraction (\%) & $\begin{array}{l}\text { Anthropogenic } \\
\text { fraction }(\%)\end{array}$ \\
\hline $\mathrm{SO}_{4}{ }^{2-}$ & 2.3 & 1.2 & 96.5 \\
\hline $\mathrm{NO}_{3}^{-}$ & - & 0.6 & 99.4 \\
\hline $\mathrm{Cl}^{-}$ & 50.2 & 1.4 & 48.4 \\
\hline $\mathrm{Ca}^{2+}$ & 0.8 & 99.2 & \\
\hline $\mathrm{Mg}^{2+}$ & 20.7 & 79.3 & \\
\hline $\mathrm{K}^{+}$ & 6.5 & 93.5 & \\
\hline
\end{tabular}

Table 3 Source contributions for different ionic constituents in rainwater anthropogenic input of $\mathrm{Cl}^{-}$could come from various pollution sources including automobile exhaust, coal combustion, and fertilizers (Négrel and Roy 1998). The majority of $\mathrm{SO}_{4}{ }^{2-}$, $\mathrm{Ca}^{2+}$, and $\mathrm{K}^{+}$appears to be of non-marine origin. Previous study revealed that $\mathrm{Ca}^{2+}$ in Beijing rainwater is mainly derived from the dissolution of $\mathrm{CaCO}_{3}$ from soil dust transported either from local areas or from desert and loess areas in northern China (Xu and Han 2009). Our data exhibit that the primary source of $\mathrm{K}^{+}$is terrestrial; $\mathrm{K}^{+}$can be also emitted by biomass burning (Khare et al. 2004).

Considering no nitrate from a marine source, the contributions from anthropogenic sources were obtained by subtracting the soil contribution from that of total nitrate in rainwater. About $99.4 \%$ of $\mathrm{NO}_{3}{ }^{-}$in Beijing Precipition was attributed to a anthropogenic source, which is mainly represented by the combustion of fossil fuel. Rainwater $\mathrm{SO}_{4}{ }^{2-}$ was characterized by only a small contribution from a crustal source, about $96.5 \%$ of total $\mathrm{SO}_{4}{ }^{2-}$ was derived by the anthropogenic sources. Aas et al. (2007) suggested that coal combustion accounts for about $70 \%$ of the commercial energy production in China, leading to a large amount of $\mathrm{SO}_{2}$ emissions, which to date represent the most important reason for acid rain in China. Besides, with the rapid increase of vehicles, $\mathrm{SO}_{2}$ from traffic is playing a more important role. To further identify the source of atmospheric sulfur, the sulfur isotopic composition of dissolved sulfate from Beijing precipitation was analyzed.

\section{Sulfur isotope composition of sulfate in precipitations}

The $\delta^{34} \mathrm{~S}$ values of dissolved sulfate in the analyzed precipitation samples ranged from +2.1 to $+12.8 \%$ with an average value for the study period of $+4.7 \pm 1.8 \%$. The maximum value was shown by a rainwater sample from a precipitation event on October $18^{\text {th }} 2010$. The minimum value was revealed by a sample taken on May $8^{\text {th }} 2011$. Compared with the 
previous report on $\delta^{34} \mathrm{~S}$ values of $\mathrm{SO}_{4}{ }^{2-}$ in the precipitation from other cities, the average $\delta^{34} \mathrm{~S}$ value of Beijing precipitation was higher than that of precipitation from Guiyang $(-2.8 \%$; Xiao et al. 2011a), Zigui $(+2.1 \%$; $\mathrm{Wu}$ and Han 2015), Nanchang (+2.1\%; Xiao et al. 2011b), and Seoul $\left(+3.7 \%\right.$; $\mathrm{Lim}$ et al. 2014). The $\delta^{34} \mathrm{~S}$ value of sulfate in precipitation in Xi'an was reported in the range of +8.71 to $+19.05 \%$ with a mean value of $+13.41 \pm 2.35 \%$ (Bai and Wang 2014), which was significantly higher than the sulfur isotope value in this study.

Figure 5 shows the $\delta^{34} \mathrm{~S}$ variation with time for the precipitation in the study area. A prominent "U"-shaped variation pattern for the $\delta^{34} \mathrm{~S}$ signatures with time can be observed. The maximum average $\delta^{34} \mathrm{~S}$ value of $+7.9 \%$ was derived from precipitation in January; the minimum value of $+3.4 \%$ originated from precipitation in August. The $\delta^{34} \mathrm{~S}$ values range from +3.4 to $+4.1 \%$ from April to September and were relatively stable with a range from +7.6 to $+7.9 \%$ in winter. In March, October, and November, the $\delta^{34} \mathrm{~S}$ values were +6.7 , +5.8 , and $+6.2 \%$, respectively. This indicates that the relative contribution of different sulfur sources to the atmosphere in this area varies with season.

There is no large scale of reducing environment in Beijing and its surroundings. Furthermore, the geographical feature in the study area is obviously different from that in South China with a rather humid climate, which is appropriate for intense rice farming. The contribution of biogenetic to atmosphere sulfate in the Beijing area should be insignificant. On the other hand, there is no active volcanism releasing volcanic sulfur into the atmosphere of the study area. Consequently, atmospheric sulfur in Beijing is mainly associated with anthropogenic source.

In China, coal is used as the main energy source and its combustion produces a large amount of $\mathrm{SO}_{2}$ released into the atmosphere (Li and Leung 2012). Previous studies (e.g., Mukai et al. 2001; Xiao and Liu 2002; Zhang et al. 2010a) have suggested that coal burning gives a significant contribution to rainwater sulfate in most Chinese cities. The $\delta^{34} \mathrm{~S}$ values of Chinese coals exhibit a very wide range $(-15$ to +

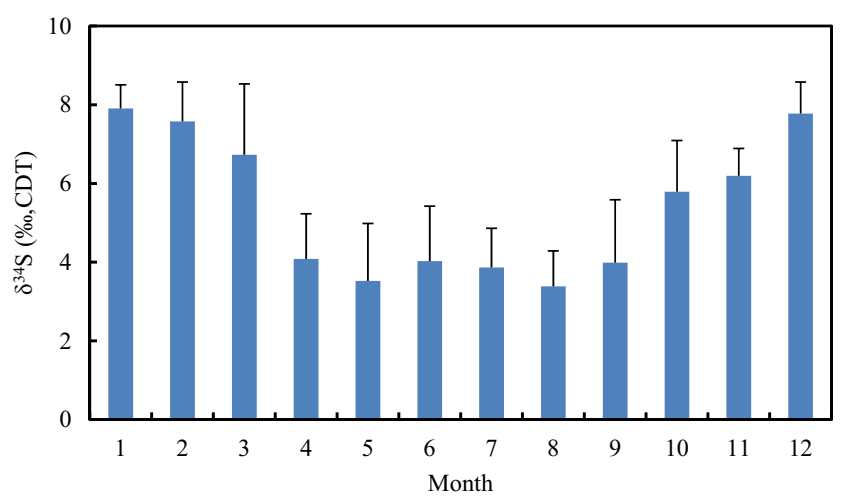

Fig. 5 Monthly variations of $\delta^{34} \mathrm{~S}$ in precipitations from Beijing
$50 \%$ ). In contrast to coals from southern China, the sulfur isotopic composition of the coals from northern China is rather positive (Xiao and Liu 2011). The central heating period in Beijing is from November 15th to March 15th characterized by intense coal combustion. In this study, the $\delta^{34} \mathrm{~S}$ values around winter are close to that of the coal from northern China ( $+7.9 \%$ in average, Maruyama et al. 2000). These observations support coal as the major source of $\mathrm{SO}_{4}{ }^{2-}$ in the precipitation of Beijing in this season.

Since the year 2000 the Beijing government has carried out numerous measures in order to control the emissions of coal combustion with the result that $\mathrm{SO}_{2}$ emissions of coal-fired power plants decreased rapidly. However, in the meantime urban traffic increased significantly up to 5.32 million registered cars in Beijing by the end of 2014. Therefore, the emissions of $\mathrm{SO}_{2}$ and sulfate particles emitted from vehicles represent another important source of $\mathrm{SO}_{4}{ }^{2-}$ in rainwater next to coal combustion (Liu et al. 2008). Norman et al. (2006) reported that sulfate from vehicle exhaust shows the $\delta^{34} \mathrm{~S}$ values of around $+5 \%$. Therefore, it can be deduced that dissolved sulfate in Beijing precipitation is contributed by a mixture of sulfate from coal burning and vehicle exhaust.

We assume that the rates of sulfur supply from local anthropogenic sources are constant throughout a year, thus, the $\delta^{34} \mathrm{~S}$ values in rainwater do not vary significantly. However, in the present study, the $\delta^{34} \mathrm{~S}$ values in October were higher than that in summer by +1.7 to $+2.4 \%$. Caron et al. (1986) and Alewell et al. (2000) pointed out that sulfur isotope fractionation may be expected in the processes of heterogeneous and homogeneous oxidation of $\mathrm{SO}_{2}$ caused by temperature change, which results in a seasonal variation of $2-3 \%$. With decreasing temperature, heterogeneous oxidation is accompanied by a large equilibrium fractionation, resulting in the accumulation of isotopically heavier sulfur. Thus, the sulfur isotope values of sulfate from precipitation in winter are higher than in summer. Accordingly, the isotopic variations with time are interpreted to result from isotopic fractionation during equilibrium reactions. This was shown in a previous study for aerosol in Beijing air (Guo et al. 2014).

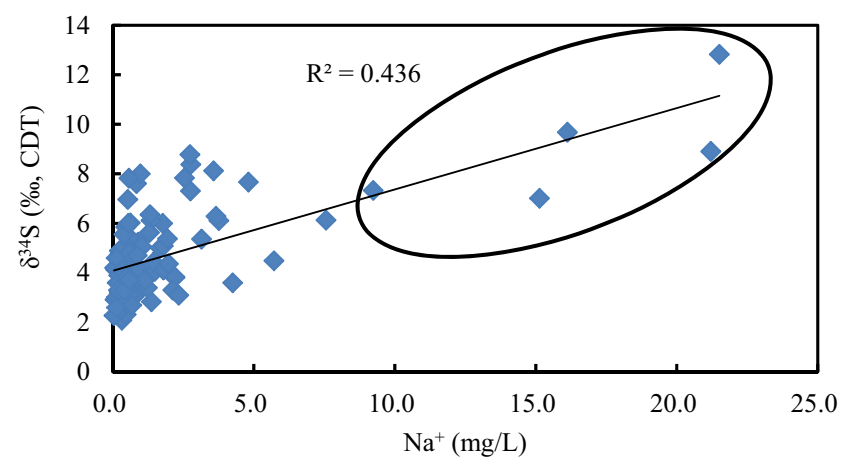

Fig. $6 \delta^{34} \mathrm{~S}-\mathrm{Na}^{+}$plot of the precipitation samples 
Seawater releases sulfate into the atmosphere by sea spray detached from the ocean surface. The isotopic composition of $\mathrm{S}$ in modern marine sulfate is relatively constant within narrow limits and with a $\delta^{34} \mathrm{~S}$ value of about $+20.1 \%$ (Wadleigh et al. 1996; Pichlmayer et al. 1998). Generally, sea spray contributes only to a negligible amount of sulfate to the total sulfate pool in inland rainwater (Herut et al. 1995), while in coastal areas, sea spray is the main source of sulfate in precipitation (Wadleigh et al. 1994). Xiao and Liu (2002) observed in Guiyang, a city in southwest China, that negative $\delta^{34} \mathrm{~S}$ values in rainwater from light rainfalls were associated with local sulfur sources while sulfur in rainwater from heavy rainfalls showed positive $\delta^{34} \mathrm{~S}$ values, which indicated a rather maritime origin. Beijing is located about $150 \mathrm{~km}$ west of the Bohai Sea. Hence, sea spray may represent one of the sources of sulfate in the precipitation of Beijing.

$\mathrm{Na}$ has been used as a reference element for sea salt, the $\delta^{34} \mathrm{~S}-\mathrm{Na}^{+}$plot can be used to identify whether rainwater is affected by sea salt (Samara et al. 1992). Figure 6 shows the relationship between the $\mathrm{Na}^{+}$concentrations and the $\delta^{34} \mathrm{~S}$ values of dissolved sulfate in Beijing precipitation. The plot shows a positive relationship between the $\mathrm{Na}^{+}$concentration and the $\delta^{34} \mathrm{~S}$ values, especially for the samples with relatively high $\mathrm{Na}^{+}$concentrations, suggesting an impact of sea spray on Beijing precipitation.

\section{Conclusions}

(1) The volume weighted average $\mathrm{pH}$ value of precipitation from Beijing was 5.02; $26.8 \%$ of the total precipitation can be classified as acid rain $(\mathrm{pH}<5.6)$; precipitation in autumn and summer displayed lower $\mathrm{pH}$ values and a higher fraction of acidic precipitation compared to those in winter and spring.

(2) The volume weighted average value of EC in precipitation was $68.6 \mu \mathrm{S} / \mathrm{cm}$, which was $\sim 4$ times higher than the background value in northern China. $\mathrm{Ca}^{2+}$ was the predominant cation, and $\mathrm{SO}_{4}{ }^{2-}$ and $\mathrm{NO}_{3}{ }^{-}$were the most abundant anions. The average $\left[\mathrm{SO}_{4}{ }^{2-}\right] /\left[\mathrm{NO}_{3}\right]$ ratio is 1.89 , with the maximum value in winter. $\mathrm{SO}_{4}{ }^{2-}$ and $\mathrm{NO}_{3}{ }^{-}$originated from anthropogenic sources, such as fossil fuel and coal combustion, $\mathrm{Ca}^{2+}, \mathrm{Mg}^{2+}$, and $\mathrm{K}^{+}$were derived from crustal sources.

(3) The average $\delta^{34} \mathrm{~S}$ values of $\mathrm{SO}_{4}{ }^{2-}$ dissolved in Beijing precipitation was $+4.7 \%$ o $(+2.1$ to $+12.8 \%$ ). There is an obvious seasonal variation apparent in the $\delta^{34} \mathrm{~S}$ signatures with higher values in winter and lower values in summer, which are mainly ascribed to isotopic fractionation of equilibrium reaction and intensive coal combustion in winter. Analysis of the $\delta^{34} \mathrm{~S}$ values confirm that sulfur in Beijing precipitation is strongly influenced by coal and fossil fuel burning; sea spray also contributed considerably to Beijing rainwater during several precipitation events.
Acknowledgments Artur Fugmann, Andreas Lutter, Jianli Wang, and Harald Strauss are thanked for their help in the laboratory. This research was financially supported by the National Basic Research Program (973) of China (No. 2014CB238906), the "One Hundred Talents" Program of the Chinese Academy of Sciences, the National High Technology Research and Development Program (863) of China (No. 2013AA06A2112), the National Natural Science Foundation of China (No.41201312, 41350110531), and the National Natural Science Foundation of China (No. 41250110528).

\section{References}

Aas W, Shao M, Jin L, Larssen T, Zhao D, Xiang R, Zhang J, Xiao J, Duan L (2007) Air concentrations and wet deposition of major inorganic ions at five nonurban sites in China, 2001-2003. Atmos Environ 41:1706-1716

Alewell C, Mitchell MJ, Likens GE, Krouse RH (2000) Assessing the origin of sulfate deposition at the Hubbard Brook Experimental Forest. J Environ Qual 29:759-767

Arsene C, Olariu RI, Mihalopoulos N (2007) Chemical composition of rainwater in the northeastern Romania, Iasi region (2003-2006). Atmos Environ 41:9452-9467

Bai L, Wang ZL (2014) Anthropogenic influence on rainwater in the Xi'an City, Northwest China: constraints from sulfur isotope and trace elements analyses. J Geochem Explor 137:65-72

Beijing Bureau of Statistics (2013) Statistical yearbook of Beijingweather condition. (in Chinese)

Berner EK, Berner RA (1987) The global water cycle. Geochemistry and Environment, Prentice-Hall, Englewood Clifs, p 394

Bytnerowicz A, Badea O, Popescu F, Musselman R, Tanase M, Barbu I, Fraczek W, Gembasu N, Surdu A, Danescu F, Postelnicu D, Cenusa R, Vasile C (2005) Air pollution, precipitation chemistry and forest health in the Retezat Mountains, Southern Carpathians, Romania. Environ Pollut 137:546-567

Calvo AI, Olmo FJ, Lyamani H, Alados-Arboledas L, Castro A, Fernández-Raga M, Fraile R (2010) Chemical composition of wet precipitation at the background EMEP station in Viznar (Granada, Spain) (2002-2006). Atmos Res 96:408-420

Canfield DE (2001) Biogeochemistry of sulfur isotopes. Rev Mineral Geochem 43:607-636

Cao YZ, Wang S, Zhang G, Luo J, Lu S (2009) Chemical characteristics of wet precipitation at an urban site of Guangzhou, South China. Atmos Res 94:462-469

Caron F, Tessier A, Kramer JR, Schwarcz HP, Rees CE (1986) Sulphur and oxygen isotopes of sulphate in precipitation and lake water, Quebec, Canada. Appl Geochem 1:601-606

Ding H, Lang YC, Liu CQ, Liu TZ (2013) Chemical characteristics and $\delta^{34} \mathrm{~S}_{-} \mathrm{SO}_{4}{ }^{2-}$ of acid rain: anthropogenic sulfate deposition and its impacts on $\mathrm{CO}_{2}$ consumption in the rural Karst area of southwest China. Geochem J 47:625-638

Evans CD, Monteith DT, Cooper DM (2005) Long-term increases in surface water dissolved organic carbon: observations, possible causes and environmental impacts. Environ Pollut 137:55-71

Guo ZB, Wu ML, Liu FL, Wei Y (2014) Multiple sulfur and oxygen isotopes in Beijing aerosol. Sci China Earth Sci 44:1556-1560

Han YX, Song LC, Xi XX, Ye YH (2005) Monthly temporal-spatial character of sandstorms and long-distance dust transport in China. China Environ Sci 25(Suppl):13-16 (in Chinese)

Herut B, Spiro B, Starinsky A, Katz A (1995) Sources of sulfur in rainwater as indicated by isotopic $\delta^{34} \mathrm{~S}$ data and chemical composition, Israel. Atmos Environ 29:851-857 
Hontoria C, Saa A, Almorox J, Cuadra L, Sanchez A, Gasco J (2003) The chemical composition of precipitation in Madrid. Water Air Soil Pollut 146:35-54

Hu GP, Balasubramanian R, Wu CD (2003) Chemical characterization of rainwater at Singapore. Chemosphere 51:747-755

Huang K, Zhuang GS, Xu C, Wang Y, Tang AH (2008) The chemistry of the severe acidic precipitation in Shanghai, China. Atmos Res 89: 149-160

Huang LM, Yang JL, Zhang GL (2012) Chemistry and source identification of wet precipitation in a rural watershed of subtropical China. Chin J Geochem 31:347-354

Khare P, Goel A, Patel D, Behari J (2004) Chemical characterization of rainwater at a developing urban habitat of Northern India. Atmos Res 69:135-145

Lang YC, Liu CQ, Li SL, Zhao ZQ, Zhou ZH (2011) Tracing natural and anthropogenic sources of dissolved sulfate in a karst region by using major ion chemistry and stable sulfur isotopes. Appl Geochem 26: S202-S205

Li R, Leung CKL (2012) Coal consumption and economic growth in China. Energ Policy 40:438-443

Likens GE, Driscoll CT, Buso DC (1996) Long-term effects of acid rain: response and recovery of a forest ecosystem. Science 272:244-246

Lim C, Jang J, Lee I, Kim G, Lee SM, Kim Y, Kim H, Kaufman AJ (2014) Sulfur isotope and chemical compositions of the wet precipitation in two major urban areas, Seoul and Busan, Korea. J Asian Earth Sci 79:415-425

Liu H, He KB, He DQ, Fu LX, Zhou Y, Walsh MP, Blumberg KO (2008) Analysis of the impacts of fuel sulfur on vehicle emissions in China. Fuel 87:3147-3154

Mandeville CW, Webster JD, Tappen C, Tayler BE, Timbal A, Sasaki A, Hauri E, Bacon CR (2009) Stable isotope and petrologic evidence for open-system degassing during the climactic and pre-climactic eruptions of Mt. Mazama, Crater Lake, Oregon. Geochim Cosmochim Ac 73:2978-3012

Maruyama T, Ohizumi T, Taneoka Y (2000) Sulfur isotope ratios of coals and oils used in China and Japan. Nippon Kagaku Kaishi 24:45-51 (In Japanese with English abstract)

Mast MA, Turk JT, Ingersoll GP, Clow DW, Kester CL (2001) Use of stable sulfur isotopes to identify sources of sulfate in Rocky Mountain snowpacks. Atmos Environ 35:3303-3313

Mukai H, Tanaka A, Fujii T, Zeng Y, Hong Y, Tang J, Guo S, Xue H, Sun Z, Zhou J, Xue D, Zhao J, Zhai G, Gu J, Zhai P (2001) Regional characteristics of sulfur and lead isotope ratios in the atmosphere at several Chinese urban sites. Environ Sci Technol 35:1064-1071

Négrel P, Roy S (1998) Chemistry of rainwater in the Massif Central (France): a strontium isotope and major element study. Appl Geochem 13:941-952

Négrel P, Guerrot C, Millot R (2007) Chemical and strontium isotope characterization of rainwater in France: influence of sources and hydrogeochemical implications. Isot Environ Healt Stud 43:179-196

Norman AL, Anlauf K, Hayden K, Thompson B, Brook JR, Li SM, Bottenheim J (2006) Aerosol sulphate and its oxidation on the Pacific NW coast: S and O isotopes in PM2.5. Atmos Environ 40: 2676-2689

Pichlmayer F, Schöner W, Seibert P, Stichler W, Wagenbach D (1998) Stable isotope analysis for characterization of pollutants at high elevation alpine sites. Atmos Environ 32:4075-4085

Pruett LE, Kreutz KJ, Wadleigh M, Aizens V (2004) Assessment of sulfate sources in high-elevation Asian precipitation using stable sulfur isotopes. Environ Sci Technol 38:4728-4733

Samara C, Tsitouridou R, Balafoutis C (1992) Chemical composition of rain in Thessaloniki, Greece, in relation to meteorological conditions. Atmos Environ Part B 26:359-367

Seto S, Hara H (2006) Precipitation chemistry in western Japan: its relationship to meteorological parameters. Atmos Environ 40:1538 1549
Shen ZX, Zhang LM, Cao JJ, Tian J, Liu L, Wang GH, Zhao ZZ, Wang X, Zhang RJ, Liu SX (2012) Chemical composition, sources, and deposition fluxes of water-soluble inorganic ions obtained from precipitation chemistry measurements collected at an urban site in northwest China. J Environ Monit 14:3000-3008

Tang J, Xue HS, Yu XL, Cheng HB, Xu XB, Zhang XC, Ji J (2000) The preliminary study on chemical characteristics of precipitation at $\mathrm{Mt}$. Waliguan. Acta Sci Circumst 20:420-425 (in Chinese)

Tang AH, Zhuang GS, Wang Y, Yuan H, Sun YL (2005) The chemistry of precipitation and its relation to aerosol in Beijing. Atmos Environ 39:3397-3406

Tang J, Xu X, Ba J, Wang S (2010) Trends of the precipitation acidity over China during 1992-2006. Chin Sci Bull 5:1800-1807

Taylor S (1964) Abundance of chemical elements in the continental crust: a new table. Geochim Cosmochim Acta 28:1273-1285

Wadleigh MA, Schwarcz HP, Kramer JR (1994) Sulphur isotope tests of seasalt correction factors in precipitation: Nova Scotia, Canada. Water Air Soil Pollut 77:1-16

Wadleigh MA, Schwarcz HP, Kramer JR (1996) Isotopic evidence for the origin of sulphate in coastal rain. Tellus B 48:44-59

Wang W, Wang T (1995) On the origin and the trend of acid precipitation in China. Water Air Soil Pollut 85:2295-2300

Wu QX, Han GL (2015) Sulfur isotope and chemical composition of the rainwater at the Three Gorges Reservoir. Atmos Res 155:130-140

Xiao HY, Liu CQ (2002) Sources of nitrogen and sulfur in wet deposition at Guiyang, Southwest China. Atmos Environ 36:5121-5130

Xiao HY, Liu CQ (2011) The elemental and isotopic composition of sulfur and nitrogen in Chinese coals. Org Geochem 42:84-93

Xiao HW, Xiao HY, Long AM, Wang YL (2011a) Sulfur isotopic geochemical characteristics in precipitation at Guiyang. Geochimica 40: 559-565 (in Chinese)

Xiao HY, Zhu RG, Lin BN, Liu CQ (2011b) Sulfur isotopic signatures in rainwater and moss Haplocladium microphyllum indicating atmospheric sulfur sources in Nanchang City (SE China). Sci Total Environ 409:2127-2132

Xiao HW, Xiao HY, Long AM, Wang YL, Liu CQ (2014) Sources and meteorological factors that control seasonal variation of $\delta^{34} \mathrm{~S}$ values in rainwater. Atmos Res 149:154-165

Xie ZQ, Du Y, Zeng Y, Li YC, Yan ML, Jiao SM (2009) Effects of precipitation variation on severe acid rain in southern China. $\mathrm{J}$ Geogr Sci 19:489-501

$\mathrm{Xu} \mathrm{ZF}$, Han GL (2009) Chemical and strontium isotope characterization of rainwater in Beijing, China. Atmos Environ 43:1954-1961

Xu H, Bi XH, Feng YC, Lin FM, Jiao L, Hong SM, Liu WG, Zhang XY (2011) Chemical composition of precipitation and its sources in Hangzhou, China. Environ Monit Assess 183:581-592

Xu ZF, Tan Y, Ji JP (2012) Chemical and strontium isotope characterization of rainwater in Beijing during the 2008 Olympic year. Atmos Res 107:115-125

Yang Z, Li XD, Deng J, Wang HY (2015) Stable sulfur isotope ratios and water-soluble inorganic compositions of PM10 in Yichang City, central China. Environ Sci Pollut Res 22:13564-13572

Zhang MY, Wang SJ, Wu FC, Yuan XH, Zhang Y (2007) Chemical compositions of wet precipitation and anthropogenic influences at a developing urban site in southeastern China. Atmos Res 84:311-322

Zhang MY, Wang SJ, Ma GQ, Zhou HZ, Fu J (2010a) Sulfur isotopic composition and source identification of atmospheric environment in central Zhejiang, China. Sci China Earth Sci 53:1-9

Zhang XM, Chai FH, Wang SL, Sun XZ, Han M (2010b) Research progress of acid precipitation in China. Res Environ Sci 23:527532 (in Chinese)

Zhang XY, Jiang H, Jin JX, Xu XH, Zhang QX (2012) Analysis of acid rain patterns in northeastern China using a decision tree method. Atmos Environ 46:590-596

Zhao DW, Xiong JL, Xu Y, Chan WH (1988) Acid-rain in Southwestern China. Atmos Environ 22:349-358 